Dr. Koenig was an honorary fellow of the Physical Society of London. He had received few tokens of recognition from academies or learned societies; and this one, conferred only last February, gave him evident pleasure. But his work, so courageously maintained in the true spirit of scientific devotion, will remain as his monument to all time.

S. P. T.

\section{THE MCCLEAN TELESCOPE AT THE CAPE OBSERVATORY.}

$\mathrm{W}^{\mathrm{E}}$ have on many occasions recorded munificent gifts towards scientific research and education from wealthy Americans and others, and now and again it has been our pleasurable duty to call attention to instances of similar generosity on the part of our own countrymen. Naturally it is more gratifying for us to record the latter than the former, especially, perhaps, as the occasions are less frequent. The weekly edition of the Cape Argus for October 2 instances a notable example of such a gift in its account of the ceremony which took place recently of the unveiling, by his Excellency the Governor (Sir W. Hely-Hutchinson), of the inscription stone of the magnificent telescope which Dr. Frank McClean, F.R.S., has presented to the Royal Observatory at the Cape. This telescope was offered and accepted some years ago, but many delays have occurred.

Says our contemporary: "The pleasant little ceremony . . . deserves more than passing mention. It gives an opportunity for the cultivation of a virtue which is not too common at the Cape-the virtue of gratitude which Shakespeare knew as a 'noble thankfulness.' And if for the nonce the public should be led to depart from its usual Philistine attitude towards pure science and the higher walks of research, the change may not be ungraceful, and may do it good. The value of $\mathrm{Mr}$. McClean's gift it would be hard to overestimate. In mere money's worth it was princely-more than the Imperial Government could well spare, and more than the Colonial Government could venture to dream of as an encouragement to unapplied science. It was given, too, at the right time and to the right place, there being immediate need for a wide development of spectroscopic work, and the southern hemisphere being poorly supplied with astronomical equipment compared with the affluent north. Further, it did not come from a mere millionaire, willing to be moderately fleeced in return for a little notoriety; Mr. McClean was a skilled and assiduous worker in this branch of science, and what he gave was the outcome of a pure heart and a noble enthusiasm. Nor did he stop at the purely material gift, but gave time and thought and trouble to make sure that the telescope and its accompaniments should be fit for the performance of the very best type of work. He came to the Cape and resided for months here, and those who were privileged to meet him will always remember his unassuming ways and his unflagging interest in his work. He had a double purpose in coming, and by far the greater portion of his time was spent in obtaining the spectra of certain southern stars, in order to supplement his similar work in the north. When this was done, the kindly English gentleman left as quietly as he came. The scientific equipment of the Colony had been handsomely enriched by him, but so far as the general public was concerned he left 'unhonoured and unsung.' . . . The need of scientific and literary endowments at the Cape is well known, and the forgetfulness of those whom the land has made wealthy is occasionally bewailed: it would ill become us, therefore, to be equally forgetful of the farseeing liberality of a stranger who owed us nothing."

The proceedings were opened, in the presence of a NO. I 669, VOL. 64] distinguished company, by Sir David Gill, K.C.B., F.R.S., His Majesty's Astronomer at the Cape, who delivered an address, space for which we regret to be unable to spare, after which Sir W. Hely-Hutchinson, in the course of a brief speech, said that in regard to the magnificent gift which Mr. McClean had made to the Observatory, he ought to say that it was the desire of H.R.H. the Duke of Cornwall and York to have performed the ceremony which he (the Governor) was now inadequately to undertake. The fact that the telescope had been named the "Victoria Telescope" was, doubtless, one reason which had actuated His Royal Highness in this regard, but the fact that so handsome-he might say, so princely-a gift had been made to science deserved the full recognition of the highest in the land. His Royal Highness not having been able, however, to unveil the inscription stone, owing to the great number of engagements which were pressed upon him during his recent visit, it had fallen to his (the Governor's) part to do so.

The whole company then proceeded to the outside of the building, where his Excellency removed the Union Jack which covered the inscription stone. The inscription was simply as follows:

\section{I897: The Victoria Telescope. \\ The Gift of Frank McClean, of Rusthall, Kent. \\ David Gill, H.M. Astronomer.}

While assembled round the stone cheers were given, first for the donor of the telescope and then for the Governor, and the proceedings terminated.

\section{THE NERNST LAMP IN AMERICA.}

THE paper read last August by Mr. A. J. Wurts at the annual convention of the American Institute of Electrical Engineers on the development of the Nernst lamp in America is especially interesting as being practically the first to contain any full description of the physical characteristics of the Nernst filament, or "glower" as it is generally called to distinguish it from the carbon filaments of incandescent lamps. It is interesting, too, in that it affords evidence that the lamp is eventually emerging from the laboratory stage and becoming a really trustworthy commercial article. It will be remembered that shortly after Nernst's invention was made public the commercial development of the lamp was taken up by four companies-by the Allgemeine Elektricitäts Gesellschaft in Germany, by the Westing house Company in America, by the Nernst Electric Light in England and by Ganz and Co. in Austria. The German company, who possess the patent rights for most of Europe, including England, have for some time had the lamp on the market in Germany, and, as their exhibit at the Glasgow Exhibition shows, are now introducing it into this country. The Westinghouse Company have also, to judge by the paper by Mr. Wurts, developed the lamp to a degree justifying its introduction into commercial use in America. Three or four years may seem to some a long time to have spent on the improvement of Nernst's invention before it could be considered practically available, but when the great complexity of the lamp as compared with an ordinary incandescent lamp is taken into account it cannot be regarded as excessive.

We propose to consider briefly some of the electrical properties of the glower as described by Mr. Wurts rather than to give a detailed account of the mechanical construction of the lamp. Those who take an interest in this side of the subject may be referred to the Electrical Review of New York for August 31 and September 7, in which will be found a full reprint of the paper and a short summary of the discussion which it raised. The 